\title{
Mood Profiling for Sustainable Mental Health among Athletes
}

\author{
Peter C. Terry ${ }^{1, *(1)}$ and Renée L. Parsons-Smith ${ }^{2,3}$ \\ 1 Centre for Health Research, University of Southern Queensland, Toowoomba 4350, Australia \\ 2 School of Psychology and Counselling, University of Southern Queensland, Toowoomba 4350, Australia; \\ renee.parsons-smith@usq.edu.au \\ 3 School of Health and Behavioural Sciences, University of the Sunshine Coast, Sippy Downs 4556, Australia \\ * Correspondence: peter.terry@usq.edu.au
}

Citation: Terry, P.C.; Parsons-Smith, R.L. Mood Profiling for Sustainable Mental Health among Athletes. Sustainability 2021, 13, 6116. https:// doi.org/10.3390/su13116116

Academic Editors: Sidonio Serpa and Jürgen Beckmann

Received: 4 March 2021

Accepted: 26 May 2021

Published: 28 May 2021

Publisher's Note: MDPI stays neutral with regard to jurisdictional claims in published maps and institutional affiliations.

\begin{abstract}
Mood responses are a well-established mental health indicator. Gauging mental health status over time often involves periodic mood assessment using a standardized measure, a process referred to as mood profiling. Comparison of observed mood scores against relevant normative data is central to effective mood profiling. The primary purpose of our study was to improve existing norms for the Brunel Mood Scale (BRUMS) using a large internet sample. The secondary purpose was to discuss how mood profiling can be used to promote sustainable mental health primarily among athletes but also with relevance to non-athletes. The BRUMS was completed via the In The Mood website by 15,692 participants. Significant differences between observed mean scores and existing normative data were evident for all six mood dimensions, prompting norm refinement. Specific group norms were generated to address sex differences in mood responses and differences by athlete/nonathlete status. The revised tables of normative data for the BRUMS should be used by researchers in future investigations of mood responses and by applied practitioners seeking to monitor mood responses as an indicator of mental health status. Applications of mood profiling with elite athletes are exemplified, along with recommendations for using mood profiling in the pursuit of sustainable mental health.
\end{abstract}

Keywords: Brunel Mood Scale; sustainability; emotion; affect; wellbeing; psychology; athlete; sport; norm

\section{Introduction}

Sustaining mental health and avoiding mental ill-health has become a significant challenge in the modern world. In 2017, it was estimated that 792 million people worldwide (i.e., $10.7 \%$ of the world's population) lived with a mental health disorder [1]. The current COVID-19 pandemic has exacerbated mental health challenges globally [2-4], including for elite athletes $[5,6]$. Assessing mood fluctuations over time is a long-established strategy for monitoring mental health [7] and establishing appropriate test norms for mood scales is a critical aspect of the process. Test norms help to determine the relative standing of an individual who has taken a test, providing the basis for comparing the raw scores of an individual to what is normal for a given population [8].

Mood profiling, whereby individual mood scores are plotted against test norms to create a graphical profile, is used to identify commonly occurring patterns of mood responses. This is often the case in investigations of the antecedents, correlates, and behavioural consequences of moods; in particular, to assess relationships between moods, performance, and psychological wellbeing of athletes and exercisers $[9,10]$. In this context, studies using the Brunel Mood Scale (BRUMS) [11,12] or the Profile of Mood States (POMS) [13,14] have identified several distinct mood profiles. For example, the iceberg profile, characterized by high scores for vigour, combined with low scores for tension, depression, anger, fatigue, and confusion, has been associated with positive mental health and good athletic performance $[15,16]$. The inverse iceberg profile, characterized by below average vigour scores, 
combined with above average tension, depression, anger, fatigue, and confusion scores, is associated with underperformance and risk of pathogenesis [17]. A third mood profile, termed the Everest profile, is characterized by higher vigour scores than the iceberg profile and lower scores for tension, depression, anger, fatigue, and confusion, and is associated with superior performance [18].

More recently, four additional mood profiles were reported in the literature, referred to as the inverse Everest, shark fin, surface, and submerged profiles [19]. The inverse Everest profile is characterized by low vigour, high tension and fatigue, and very high depression, anger, and confusion; the shark fin profile by below average tension, depression, anger, vigour, and confusion, combined with high fatigue; the surface profile by average scores on all mood dimensions; and the submerged profile by below average scores on all mood dimensions. These four profiles, together with the iceberg and inverse iceberg profiles, have been replicated in several different contexts, including English-speaking and Italianspeaking sport participants [20,21], among a representative sample of the Singaporean population [22], and among the large, heterogeneous sample interrogated in the present study [23], suggesting that the profile clusters are robust across different language and cultural contexts. Figure 1 shows the prevalence of the six mood profiles reported by Terry and colleagues [23].

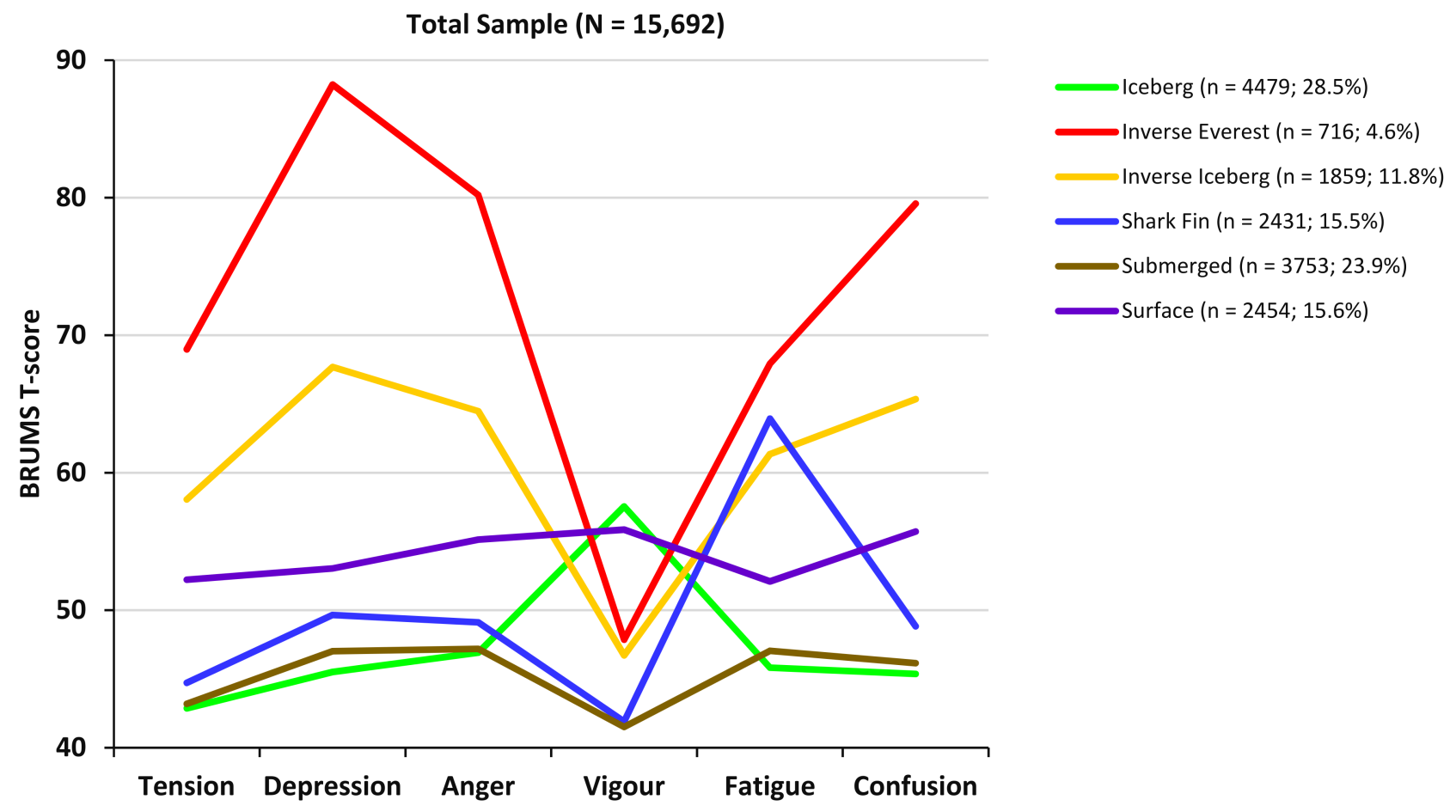

Figure 1. Graphical representation of six mood profile clusters [23].

Mood profiling scales, such as the BRUMS, have many applications globally. The measure has been used to, for example, quantify affective responses to music in Australia [24]; screen for risk of post-traumatic stress disorder among military personnel in South Africa [25]; evaluate population-level mental health and monitor the psychological wellbeing of cardiac rehabilitation patients in Brazil [26,27]; manage performance anxiety and prevent injuries among adolescent ballet dancers in Japan [28]; and assess youth for elevated suicide risk in the USA [29]. A variety of BRUMS applications are prevalent in sport, including performance prediction; monitoring athlete mindset; assessing mood responses to poor performance, training load, injury, or long haul travel; screening for risk of overtraining, eating disorders, and other pathogenic conditions; and as a general catalyst for discussion between an athlete and sport psychologist [18]. 
Since the original norms for the BRUMS were generated, much larger samples of the population have been tested. Previous analysis of the large, heterogeneous dataset used in the present investigation [23] showed that the mean scores deviated significantly from existing normative data on all subscales, highlighting the need for refinement of the norms. Further, significant between-group differences were evident for sex, age group, and educational status, suggesting that separate norms should be considered for specific demographic groups. Finally, it has long been established that athletes typically report mood profiles that vary from other populations [12,30], pointing to the need for athletespecific norms.

The primary purpose of the current study was to improve existing norms for the BRUMS [31] using a large internet sample of participants. The secondary purpose was to discuss how mood profiling can be used to promote sustainable mental health among athletes. Our study was predicated on the production of improved norms for the BRUMS and therefore no other measures of mood were considered.

\section{Materials and Methods}

\subsection{Participants}

A heterogeneous sample of 15,692 participants was recruited, which included approximately equal representation of males $(n=8450 ; 53.8 \%)$ and females $(n=7242 ; 46.2 \%)$. The age group distribution of participants was 18-24 yr $(n=9765 ; 62.2 \%), 25-35 \mathrm{yr}(n=3212$; $20.5 \%), 36-45$ yr $(n=1348 ; 8.6 \%), 46-55$ yr $(n=916 ; 5.8 \%)$, and $56+(n=451 ; 2.9 \%)$. The ethnic composition of the sample was Caucasian $(n=8465 ; 53.9 \%)$, Asian $(n=2987 ; 19.0 \%)$, African $(n=945 ; 6.0 \%)$, Middle Eastern $(n=384 ; 2.4 \%)$, Indigenous $(n=147 ; 0.9 \%)$, and Other $(n=2764 ; 17.6 \%)$. A total of 3120 participants $(19.9 \%)$ of the sample were athletes, and 12,572 were non-athletes $(80.1 \%)$.

\subsection{Measures}

The 24-item Brunel Mood Scale (BRUMS) was used to assess mood responses. It has six subscales (tension, depression, anger, vigour, fatigue, and confusion) of four mood descriptors each, with respondents rating how they feel "right now" on a 5-point Likert-type scale anchored by $0=$ not at all and $4=$ extremely. During its development, the BRUMS showed robust psychometric properties across samples of adult students, adult athletes, young athletes, and schoolchildren [11,12], and has since demonstrated psychometric integrity for use with many other population groups. It has been translated and validated in several languages and cultural contexts, including Afrikaans [32], Brazilian Portuguese [33], Chinese [34], Czech [35], French [36], Hungarian [37], Italian [37,38], Japanese [39], Malay [40,41], Persian [42], Singaporean [43], Spanish [44], and Turkish [45]. The BRUMS does not provide a comprehensive assessment of mood in its broadest sense [46], so researchers using the measure are cautioned not to extrapolate findings beyond the six specific mood dimensions assessed. The In The Mood website [47] facilitates completion of the BRUMS online, providing an instant calculation and interpretation of individual mood responses. An automated report is generated, including raw and standard scores, reference to normative scores, a graphical representation of the individual mood profile, and suggested evidence-based mood regulation strategies, where appropriate. Adult participants ( $\geq 18$ years) were recruited using a snowballing strategy and directed to the In The Mood website during the period March 2011 to January 2018. Data analyses were conducted using IBM SPSS Statistics for Windows, Version 27 [48].

\section{Results}

\subsection{Data Screening}

The In The Mood website requires respondents to answer all items prior to submission, and therefore no missing values were detected. The full range of possible subscale scores from $0-16$ was evident for all subscales. Data were screened for implausible responses (e.g., scoring 0 or 16 on every subscale) and cases deleted where identified. Significant 
deviation from univariate normality was evident for some subscales (e.g., depression), which is common for negative mood score distributions [12]. Given the very large sample size, it was judged that the level of non-normality identified would not unduly affect the findings.

\subsection{Between-Group Differences and Generation of Revised Norms}

Previous findings [23] showed that mean mood scores for the sample overall deviated significantly from existing normative data on all six subscales, with effects sizes ranging from 0.07 to 0.29 . Although the effect sizes were small [49], differences of this magnitude in such a large dataset were judged to warrant the generation of revised tables of normative data. Revised norms in the form of standard T-scores were produced using the formula $\mathrm{T}=50+10 \mathrm{z}[50]$.

Single-factor MANOVAs of mood scores by sex (male/female) and athletic status (athlete/non-athlete) produced significant main effects for sex (Wilks' $\Lambda=0.968 ; \mathrm{F}=85.70$, $p<0.001, \eta^{2}=0.032$ ) and athletic status (Wilks' $\Lambda=0.976 ; \mathrm{F}=64.42, p<0.001, \eta^{2}=0.024$; see Table 1). Tension, fatigue, and confusion scores were significantly higher among females $(p<0.001)$, whereas anger $(p=0.003)$ and vigour scores $(p<0.001)$ were significantly higher among males. No sex differences were found for depression. Athletes reported significantly higher scores than non-athletes $(p<0.001)$ for tension, depression, anger, vigour, and confusion. No athletic status difference was found for fatigue. Effect sizes were mostly negligible, and the maximum variance explained by any univariate comparison was $1.8 \%$. A 2-way MANOVA showed a significant multivariate interaction effect $\left(\mathrm{F}=5.34, p<0.001, \eta^{2}=0.002\right)$. Significant interactions were found for fatigue $(p<0.001)$ and confusion $(p=0.004)$. Female athletes reported the highest fatigue scores whereas male athletes reported the lowest. Female athletes reported higher confusion scores than the other three groups. Given the number of significant between-group differences, separate norms were generated for each of the four groups.

The generation of group-specific norms was restricted in this study to sex and athletic status. Separate norms by age group and educational status were not generated because (a) between-group differences were generally very small for age and education, and more importantly because (b) the resultant large number of highly specific tables of norms would have yielded very little practical value.

Tables 2-6 contain revised norms for the overall sample, for male and female athletes, and for male and female non-athletes. The norms reflect differences in raw scores both within and across groups. For example, among female athletes, a T-score of 50 equates to a raw score of 4 for tension but a raw score of 8 for vigour (see Table 3). Similarly, a T-score of 50 equates to a raw score of 5 for fatigue among male athletes but a raw score of 6 among female athletes (see Tables 2 and 3). Figure A1 in Appendix A shows the overall norms in a format that allows the profile for an individual or group to be plotted graphically. Equivalent profile sheets for male and female athletes and male and female non-athletes are contained in Figure A2 to Figure A5. 
Table 1. Comparison of the BRUMS scores by sex and athlete/non-athlete status.

\begin{tabular}{|c|c|c|c|c|}
\hline Source & $n(\%)$ & $M$ & $S D$ & $95 \% \mathrm{CI}$ \\
\hline \multicolumn{5}{|c|}{$\operatorname{Sex}\left(\right.$ Wilks' $^{\prime} \Lambda=0.968, F(6,15685)=85.70^{\dagger}$, partial $\left.\eta^{2}=0.032\right)$} \\
\hline Male & $8450(53.8)$ & & & \\
\hline Tension & & $47.11^{\dagger}$ & 8.60 & $(46.92,47.29)$ \\
\hline Depression & & 52.09 & 12.07 & $(51.83,52.34)$ \\
\hline Anger & & $52.44 \S$ & 10.58 & $(52.21,52.66)$ \\
\hline Vigour & & $50.41^{+}$ & 9.54 & $(50.21,50.61)$ \\
\hline Fatigue & & $51.98^{+}$ & 9.39 & $(51.78,52.18)$ \\
\hline Confusion & & $51.34^{\dagger}$ & 10.54 & $(51.11,51.56)$ \\
\hline Female & $7242(46.2)$ & & & \\
\hline Tension & & 48.35 & 9.14 & $(48.14,48.56)$ \\
\hline Depression & & 52.47 & 12.43 & $(52.19,52.76)$ \\
\hline Anger & & 51.94 & 10.12 & $(51.71,52.17)$ \\
\hline Vigour & & 48.00 & 9.40 & $(47.79,48.22)$ \\
\hline Fatigue & & 53.64 & 9.78 & $(53.42,53.87)$ \\
\hline Confusion & & 52.00 & 11.12 & $(51.74,52.25)$ \\
\hline \multicolumn{5}{|c|}{ Athlete Status $\left(W_{i l k s} \Lambda=0.976, F(6,15685)=64.42^{\dagger}\right.$, partial $\left.\eta^{2}=0.024\right)$} \\
\hline Athletes & $3120(19.9)$ & & & \\
\hline Tension & & $48.43^{\dagger}$ & 9.05 & $(48.12,48.74)$ \\
\hline Depression & & $52.88^{\dagger}$ & 12.24 & $(52.45,53.31)$ \\
\hline Anger & & $53.70^{\dagger}$ & 11.17 & $(53.33,54.06)$ \\
\hline Vigour & & $51.89^{\dagger}$ & 9.28 & $(51.56,52.23)$ \\
\hline Fatigue & & 52.48 & 9.30 & $(52.14,52.82)$ \\
\hline Confusion & & $52.21^{\dagger}$ & 10.49 & $(51.83,52.59)$ \\
\hline Non-athletes & $12,572(80.1)$ & & & \\
\hline Tension & & 47.50 & 8.82 & $(47.34,47.65)$ \\
\hline Depression & & 52.11 & 12.23 & $(51.90,52.33)$ \\
\hline Anger & & 51.84 & 10.13 & $(51.66,52.02)$ \\
\hline Vigour & & 48.65 & 9.51 & $(48.49,48.82)$ \\
\hline Fatigue & & 52.82 & 9.68 & $(52.65,52.98)$ \\
\hline Confusion & & 51.50 & 10.88 & $(51.31,51.69)$ \\
\hline
\end{tabular}

Table 2. BRUMS normative scores for the whole sample $(n=15,692)$.

\begin{tabular}{ccccccc}
\hline \multirow{2}{*}{ Raw Score } & \multicolumn{5}{c}{ T-Score } \\
\cline { 2 - 6 } & Tension & Depression & Anger & Vigour & Fatigue & Confusion \\
\hline 0 & 41 & 43 & 43 & 31 & 37 & 42 \\
1 & 44 & 46 & 46 & 33 & 39 & 45 \\
2 & 47 & 50 & 49 & 36 & 42 & 48 \\
3 & 50 & 53 & 53 & 38 & 44 & 52 \\
4 & 53 & 56 & 56 & 41 & 47 & 55 \\
5 & 56 & 59 & 59 & 44 & 49 & 58 \\
6 & 59 & 62 & 62 & 46 & 52 & 61 \\
7 & 62 & 65 & 65 & 49 & 54 & 64 \\
8 & 65 & 69 & 69 & 52 & 57 & 68 \\
9 & 68 & 72 & 72 & 54 & 59 & 71 \\
10 & 71 & 75 & 75 & 57 & 62 & 74 \\
11 & 74 & 78 & 78 & 59 & 65 & 77 \\
12 & 77 & 81 & 81 & 62 & 67 & 81 \\
13 & 80 & 84 & 85 & 65 & 70 & 84 \\
14 & 83 & 88 & 88 & 67 & 72 & 87 \\
15 & 86 & 91 & 91 & 70 & 75 & 90 \\
16 & 89 & 94 & 94 & 72 & 77 & 93 \\
\hline
\end{tabular}


Table 3. BRUMS normative scores for male athletes $(n=2243)$.

\begin{tabular}{ccccccc}
\hline \multirow{2}{*}{ Raw Score } & \multicolumn{7}{c}{ T-Score } \\
\cline { 2 - 6 } & Tension & Depression & Anger & Vigour & Fatigue & Confusion \\
\hline 0 & 41 & 43 & 42 & 27 & 37 & 41 \\
1 & 44 & 46 & 45 & 29 & 40 & 45 \\
2 & 47 & 49 & 48 & 32 & 42 & 48 \\
3 & 50 & 53 & 51 & 35 & 45 & 52 \\
4 & 53 & 56 & 54 & 38 & 48 & 55 \\
5 & 56 & 59 & 57 & 40 & 50 & 58 \\
6 & 59 & 63 & 60 & 43 & 53 & 62 \\
7 & 62 & 66 & 63 & 46 & 56 & 65 \\
8 & 65 & 69 & 66 & 48 & 59 & 68 \\
9 & 68 & 72 & 69 & 51 & 61 & 72 \\
10 & 71 & 76 & 72 & 54 & 64 & 75 \\
11 & 74 & 79 & 75 & 56 & 67 & 79 \\
12 & 77 & 82 & 78 & 59 & 69 & 82 \\
13 & 80 & 85 & 81 & 62 & 72 & 85 \\
14 & 83 & 89 & 84 & 65 & 75 & 89 \\
15 & 86 & 92 & 87 & 67 & 78 & 92 \\
16 & 89 & 95 & 90 & 70 & 80 & 96 \\
\hline
\end{tabular}

Table 4. BRUMS normative scores for female athletes $(n=877)$.

\begin{tabular}{ccccccc}
\hline \multirow{2}{*}{ Raw Score } & \multicolumn{7}{c}{ T-Score } \\
\cline { 2 - 6 } & Tension & Depression & Anger & Vigour & Fatigue & Confusion \\
\hline 0 & 39 & 42 & 42 & 28 & 35 & 40 \\
1 & 42 & 45 & 45 & 31 & 38 & 43 \\
2 & 45 & 48 & 48 & 34 & 40 & 46 \\
3 & 48 & 51 & 51 & 36 & 43 & 50 \\
4 & 50 & 54 & 54 & 39 & 45 & 53 \\
5 & 53 & 57 & 57 & 42 & 47 & 56 \\
6 & 56 & 60 & 60 & 45 & 50 & 59 \\
7 & 59 & 63 & 63 & 47 & 52 & 63 \\
8 & 62 & 66 & 66 & 50 & 55 & 66 \\
9 & 65 & 69 & 69 & 53 & 57 & 69 \\
10 & 67 & 72 & 72 & 55 & 60 & 72 \\
11 & 70 & 75 & 75 & 58 & 62 & 76 \\
12 & 73 & 78 & 78 & 61 & 65 & 79 \\
13 & 76 & 81 & 81 & 64 & 67 & 82 \\
14 & 79 & 84 & 84 & 66 & 70 & 85 \\
15 & 82 & 87 & 87 & 69 & 72 & 92 \\
16 & 84 & 90 & 90 & 72 & 75 & 95 \\
\hline
\end{tabular}

Table 5. BRUMS normative scores for male non-athletes $(n=6207)$.

\begin{tabular}{ccccccc}
\hline \multirow{2}{*}{ Raw Score } & \multicolumn{7}{c}{ T-Score } \\
\cline { 2 - 6 } & Tension & Depression & Anger & Vigour & Fatigue & Confusion \\
\hline 0 & 42 & 44 & 43 & 30 & 37 & 42 \\
1 & 45 & 47 & 46 & 33 & 40 & 45 \\
2 & 48 & 50 & 50 & 35 & 42 & 49 \\
3 & 51 & 53 & 53 & 38 & 45 & 52 \\
4 & 54 & 56 & 56 & 41 & 47 & 55 \\
5 & 57 & 59 & 59 & 43 & 50 & 59 \\
6 & 60 & 63 & 62 & 46 & 53 & 62 \\
7 & 64 & 66 & 66 & 48 & 55 & 65 \\
\hline
\end{tabular}


Table 5. Cont.

\begin{tabular}{ccccccc}
\hline \multirow{2}{*}{ Raw Score } & \multicolumn{7}{c}{ T-Score } \\
\cline { 2 - 6 } & Tension & Depression & Anger & Vigour & Fatigue & Confusion \\
\hline 8 & 67 & 69 & 69 & 51 & 58 & 68 \\
9 & 70 & 72 & 72 & 54 & 60 & 72 \\
10 & 73 & 75 & 75 & 56 & 63 & 75 \\
11 & 76 & 79 & 79 & 59 & 65 & 78 \\
12 & 79 & 82 & 82 & 62 & 68 & 82 \\
13 & 82 & 85 & 85 & 64 & 70 & 85 \\
14 & 86 & 88 & 88 & 67 & 73 & 88 \\
15 & 89 & 91 & 91 & 69 & 75 & 91 \\
16 & 92 & 95 & 95 & 72 & 78 & 95 \\
\hline
\end{tabular}

Table 6. BRUMS normative scores for female non-athletes $(n=6365)$.

\begin{tabular}{ccccccc}
\hline \multirow{2}{*}{ Raw Score } & \multicolumn{7}{c}{ T-Score } \\
\cline { 2 - 6 } & Tension & Depression & Anger & Vigour & Fatigue & Confusion \\
\hline 0 & 41 & 43 & 43 & 32 & 36 & 42 \\
1 & 44 & 47 & 46 & 35 & 39 & 45 \\
2 & 47 & 50 & 50 & 37 & 41 & 48 \\
3 & 50 & 53 & 53 & 40 & 44 & 51 \\
4 & 53 & 56 & 57 & 43 & 46 & 55 \\
5 & 55 & 59 & 60 & 45 & 49 & 58 \\
6 & 58 & 62 & 63 & 48 & 51 & 61 \\
7 & 61 & 65 & 67 & 51 & 54 & 64 \\
8 & 64 & 68 & 70 & 53 & 56 & 67 \\
9 & 67 & 72 & 73 & 56 & 59 & 70 \\
10 & 70 & 75 & 77 & 59 & 61 & 73 \\
11 & 73 & 78 & 80 & 61 & 64 & 76 \\
12 & 76 & 81 & 83 & 64 & 66 & 80 \\
13 & 79 & 84 & 87 & 67 & 69 & 83 \\
14 & 82 & 87 & 90 & 69 & 71 & 86 \\
15 & 85 & 90 & 93 & 72 & 74 & 89 \\
16 & 88 & 93 & 97 & 75 & 76 & 92 \\
\hline
\end{tabular}

\section{Discussion}

The mental health of athletes, especially at the elite level, has come under intense scrutiny in recent years [51-55], although the International Olympic Committee consensus statement on mental health among elite athletes [55] pointed out that "there are no evidencebased or consensus-based guidelines for diagnosis and management of mental health symptoms and disorders in elite athletes" (p. 667). Given this gap in the provision of reliable guidelines for diagnosis of mental health issues, strategies such as mood profiling that provide indicators of increased risk of psychopathology become especially valuable in protecting mental wellbeing in a sustainable way. This point has been emphasized in recent calls for early intervention frameworks to be implemented in elite sport environments: "Early detection of, and intervention for, mental health symptoms is essential in the elite sporting context" [56]. Indeed, psychological measures have relevance as part of broader health-screening programs for athletes, aimed at maintaining both physical and mental health and, in this context, mood profiling has been shown to have utility in predicting athletic injury [57,58].

The prevalence of mental health symptoms and disorders among elite athletes broadly reflects the prevalence rates found in the general population [59]. A recent meta-analysis showed the prevalence among current elite athletes ranged from $19 \%$ for alcohol misuse to $34 \%$ for anxiety/depression, and from $16 \%$ for distress to $26 \%$ for anxiety/depression among former elite athletes [60]. With prevalence rates at such alarmingly high levels, 
regular screening of athlete populations for mental ill-health indicators represents an essential element of high-performance environments [52]. Mood profiling may also have a role to play in the detection of potentially life-threatening mental illnesses, such as eating disorders. Although involvement in sport may offer some protection against disordered eating, sub-clinical and clinical eating disorders are generally shown to be more prevalent in athletes than the general population, more prevalent among female athletes than male athletes, and more prevalent in leanness-dependent and weight-dependent sports than in other sports [61-64]. Further, mood disorders, especially depression and anxiety, are among the most common comorbidities associated with eating disorders [65] and therefore screening for such symptoms via mood profiling offers a quick and simple method for identifying candidates for follow-up clinical interview.

In terms of the specific mood profiles identified in this paper (Figure 1) and previously [19-23], the inverse Everest and inverse iceberg profiles, both typified by high or very high scores for tension, depression, anger, fatigue, and confusion, would logically represent reliable indicators of elevated risk of mental health concerns. However, such profiles may represent acute emotional responses to a specific incident (e.g., a devastating sporting defeat or a debilitating injury) after which emotions might subside quite quickly, rather than a more enduring state of mind indicative of mental ill-health. Hence, it is recommended that periodic mood profiling repeated over time provides a better indicator of mental wellbeing. To discuss the practicalities of how mood profiling can be used, reference is made below to several real-life examples from the first author's experiences of working with elite athletes over several decades, including providing on-site psychological support at nine Olympic Games and more than 100 other international sporting events.

Figure 2 shows the mood profiles of a medal-winning athlete during an Olympic Winter Games. The athlete initially reported a submerged profile during the 15-day to 12-day pre-competition phase, with scores for all mood dimensions sitting below the athlete population mean. Having worked with the athlete over several years, this profile was recognizable as him feeling flat and emotionally drained from inter-continental travel and a period of hard physical training but represented no threat to mental wellbeing. During the 9-day to 6-day pre-competition phase, scores for depression and anger spiked, signalling the need for some form of intervention. Discussions with the athlete identified the source of the feelings as relating to a family issue that he felt powerless to resolve, given the impending Olympic competition and his physical distance from home. Considering the truism that "at the Olympics, everything is a performance issue" [66], the situation represented both a threat to mental wellbeing and to successful performance. Once strategies that at least partly resolved the family issue has been implemented, his mood improved incrementally towards the crucial second day of competition when the more desirable iceberg profile was evident, except for tension being marginally higher than the norm.

Figure 3 shows the mood profiles of an Olympic champion throughout the Games period. Mood profiling commenced the day after arrival in the Olympic city and continued until the morning of competition. The profiles show an early adjustment to the effects of long-distance travel and associated jetlag, in the form of a shark fin profile. Next, an extended period of stable positive mood is evident, in the form of successive iceberg profiles, with a slight increase in tension as competition approached. The optimum mood for this athlete had been identified at previous competitions and therefore the challenge was to identify when the optimum mood was achieved and to maintain it using a variety of preplanned strategies. The athlete had found the previous Olympic Games to be emotionally overwhelming and therefore he opted out of the Olympic Village environment, instead staying in a rented house with a fellow athlete, the team coaches, and the team psychologist (the first author). The athlete used his own transport, shopped for his own food, and a "home away from home" environment was created, which helped to stabilize his mood. Notably, his standard scores for depression, anger, and confusion represented raw scores of zero on those mood dimensions throughout the entire Games period. 


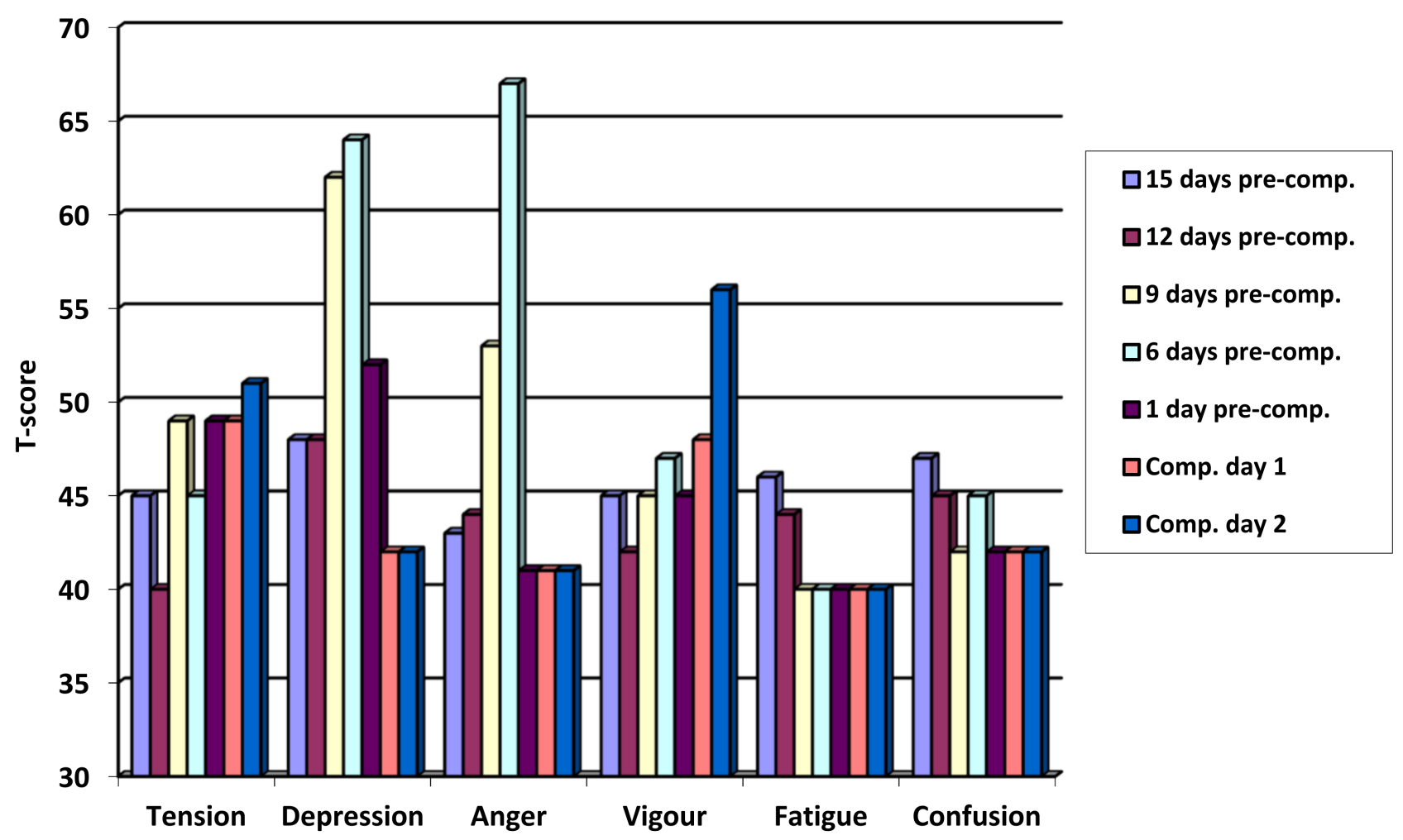

Figure 2. Mood profiles of a medal-winning athlete at the Olympic Winter Games.

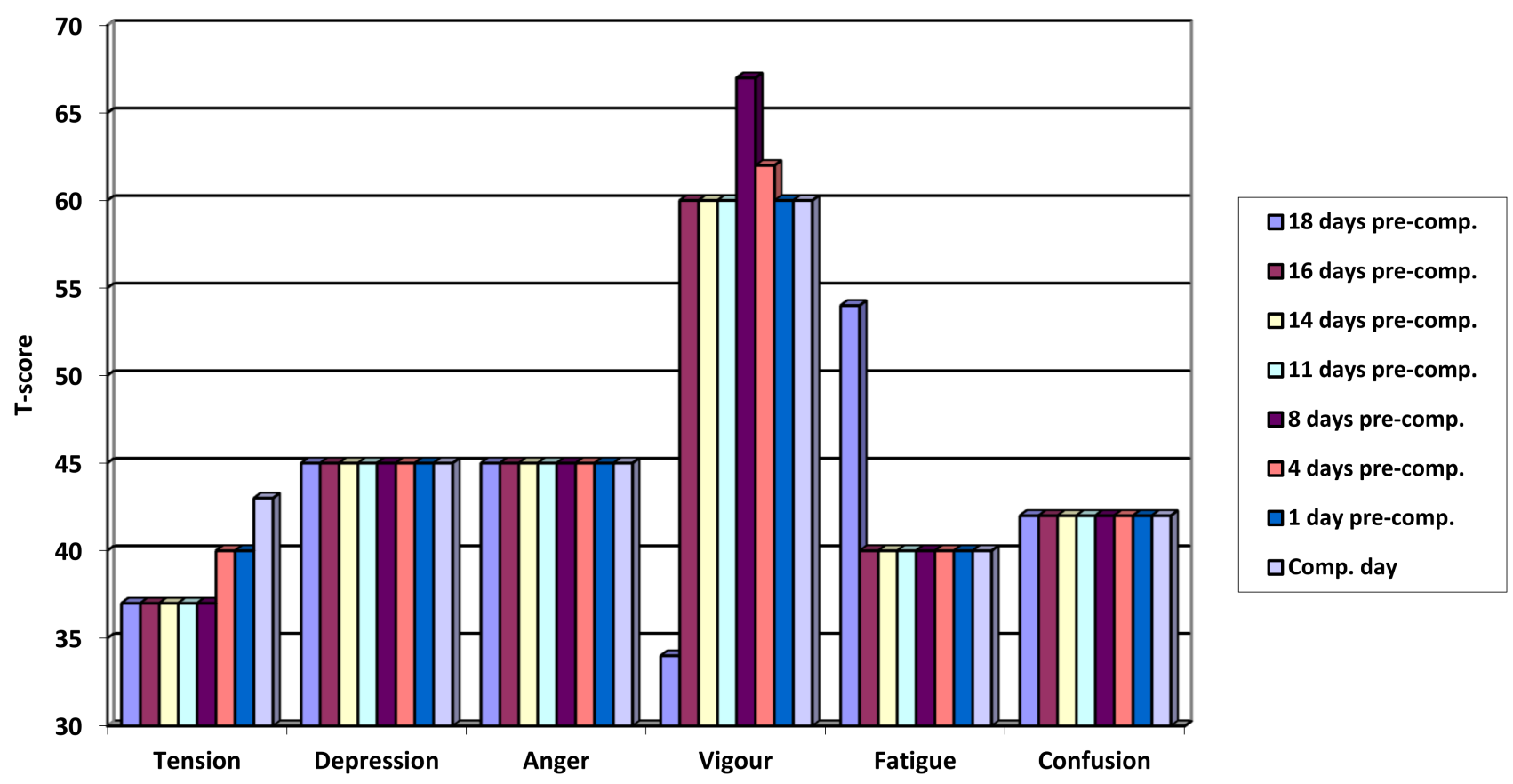

Figure 3. Mood profiles of an Olympic champion during the Olympic Summer Games.

Figure 4 shows the post-competition mood profiles of an underperforming Olympian. His mood the day after a disappointing Olympic competition showed an extreme inverse Everest profile, representing a clear threat to his mental wellbeing. Successive profiles taken in the following days showed the progress of his emotional recovery, although even his most positive profile during the period, at 12 days post-competition, approximated an inverse iceberg, representing a continuing elevated mental health risk. Even years later, 
the memory of that underperformance still haunts the athlete but thankfully his mental wellbeing remains intact.

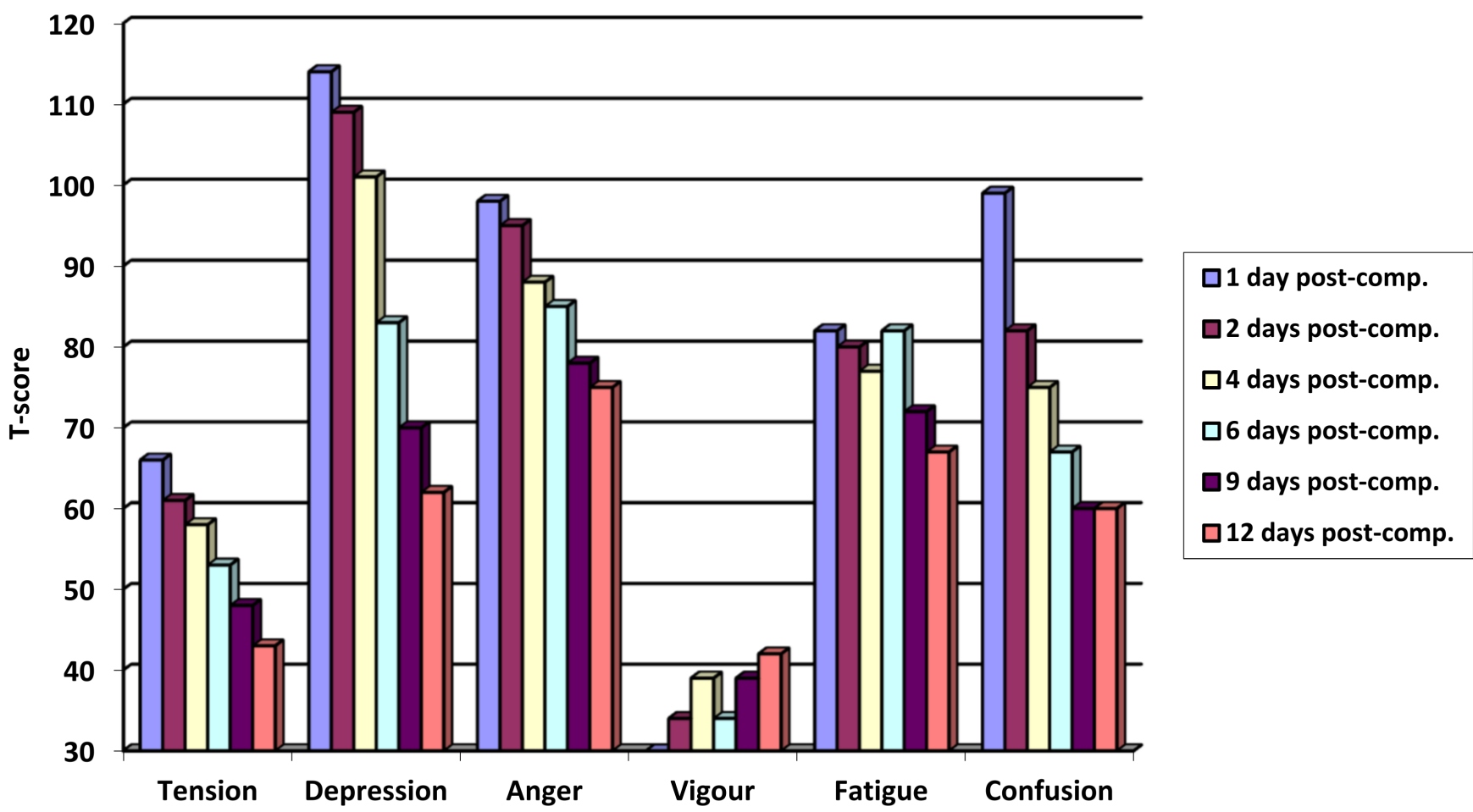

Figure 4. Post-competition mood profiles of an underperforming athlete at the Olympic Summer Games.

Figure 5 shows the mood profiles of a 6-time world champion over a 2-year period, during which time she received a clinical diagnosis of chronic fatigue syndrome (CFS) $[17,67]$. Having received advice from an eminent sports medic that "her body was telling her that it's time to stop competing", she experienced a rapid decline in mental health, reflected in an inverse Everest profile two years out from her eventual return to competition. She tried multiple unsuccessful clinical and alternative therapies over the next year, during which time her mental ill-health continued, and her mood profiles remained extremely negative.

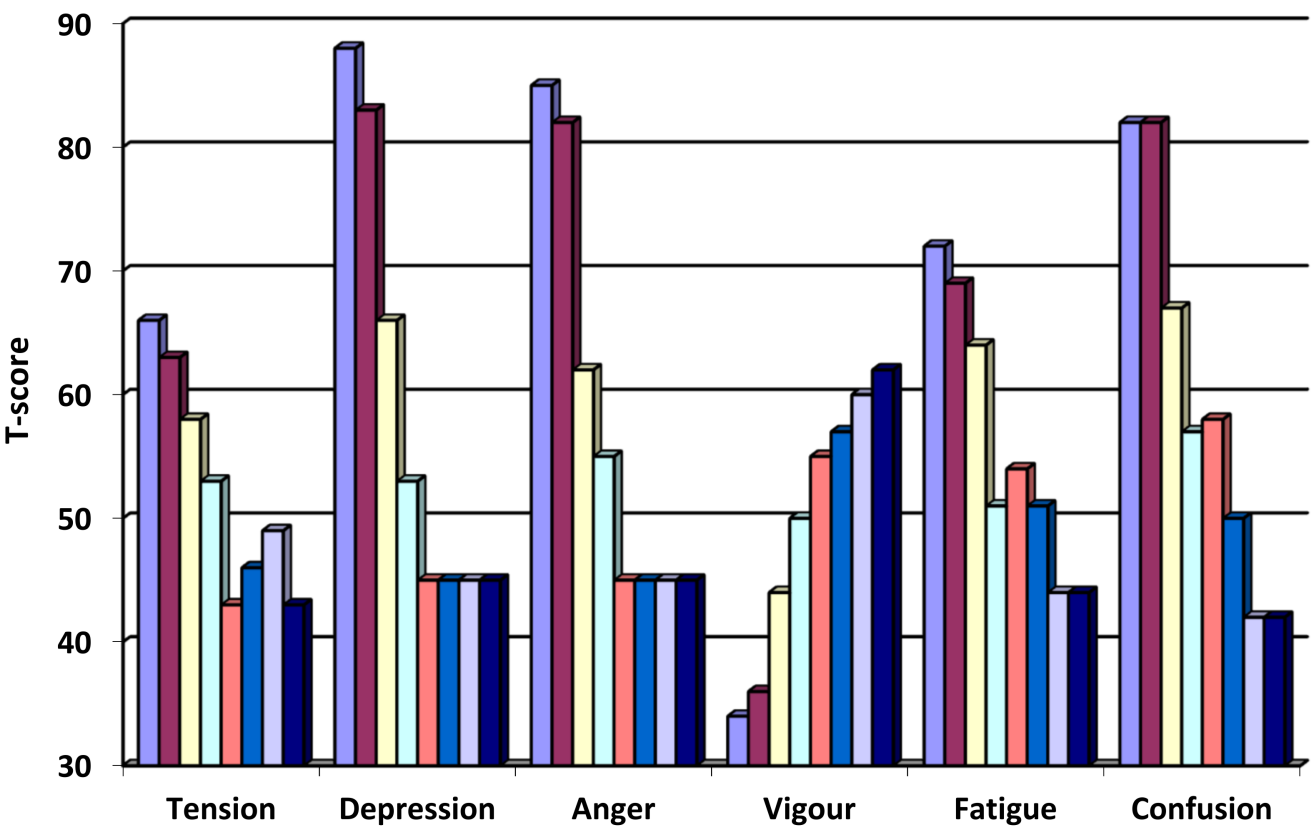

$\square 2$ years pre-comp.

$\square 1$ year pre-comp.

$\square 6$ months pre-comp.

$\square 3$ months pre-comp.

$\square 3$ days pre-comp.

$\square 2$ days pre-comp.

$\square 1$ day pre-comp.

- Race day

Figure 5. Mood profiles of a gold medal athlete prior to the World Championship. 
She eventually committed to an extended period of reverse therapy [68], which treats CFS as a disorder of the hypothalamus-pituitary-adrenal axis and offers an educative process focusing on, for example, the link between emotions and health, and finding a balance between training load and life demands. She recounted how the same personal strengths that helped her become world champion-commitment, single-mindedness, focus, and dedication - contributed to the demise of her physical and mental health [69]. Her vigilance, bordering on obsession, in always doing the right thing in training, diet, sleep patterns, and so on, drained her happiness and love of sport to the point where she felt permanently exhausted.

Through reverse therapy, her mental and physical health progressively improved, reflected in more positive mood profiles, until she was ready to return to competition. Her mood responses leading into the world championship showed rising vigour scores and decreasing fatigue scores. Depression and anger scores remained stable at minimum levels. Confusion was eliminated by race day as her race plan became more clearly understood and well-rehearsed. Tension fluctuated but remained within the normal range. Her prerace iceberg profile was consistent with her previous successful performances and she achieved one of the most convincing victories of her career.

In summary, mental health issues are likely to be experienced in one form or another by $30-50 \%$ of elite athletes during their lifetime $[60,70,71]$. Symptoms tend to first manifest in the late teens to early twenties age range, often with recurrent episodes later in life [71]. Common mental health issues experienced by athletes include depression, anxiety, eating disorders, chronic fatigue, alcohol misuse, and sleep disorders [51,60,70,71]. Each of these conditions is likely to manifest in mood decrements, and hence negative mood profiles (i.e., inverse Everest, inverse iceberg, and to a lesser extent the shark fin profile) indicate elevated risk of a potential mental health issue. Factors that protect against mental health issues among elite athletes include positive interpersonal relationships within sport and athletes' private lives, adequate recovery from the physical demands of training and competition that are an inherent part of elite sport, and feelings of autonomy over sporting careers and lives more generally [72]. Mood profiling has a long history of use to help guard against risk of overtraining and burnout among athletes [16,17] and as a general monitor of psychological wellbeing [18,73]. The examples provided above describe how mood profiling has been used with specific elite athletes to help safeguard both the performance and mental health of the individuals concerned. Table 7 contains recommendations to applied practitioners for using mood profiling in the pursuit of sustainable mental health for athletes.

Table 7. Recommendations for the use of mood profiling with athletes.

\begin{tabular}{cl}
\hline Recommendation & Explanation \\
\hline Profile moods regularly. & $\begin{array}{l}\text { A single mood profile has limited value compared to mood } \\
\text { trends over time. Weekly profiles act as a useful monitor of } \\
\text { general well-being but more frequent, even daily, profiling may } \\
\text { be beneficial in major competitions, when moods may be more } \\
\text { volatile [18]. Mood stability is proposed to be advantageous for } \\
\text { performance [74]. }\end{array}$ \\
\hline $\begin{array}{c}\text { Ensure individual } \\
\text { follow-up. }\end{array}$ & $\begin{array}{l}\text { One-to-one discussion is recommended to better understand the } \\
\text { context of a mood profile. Reasons underlying specific mood } \\
\text { scores (e.g., elevated angerdue to a disagreement with a } \\
\text { teammate; increased fatigue due to inadequate sleep) can be } \\
\text { addressed to help guide future actions or interventions [18]. }\end{array}$ \\
\hline $\begin{array}{c}\text { Consider referral of athletes } \\
\text { with very negative profiles. }\end{array}$ & $\begin{array}{l}\text { Inverse iceberg and, especially, inverse Everest profiles suggest } \\
\text { risk of psychopathology. Such profiles repeated over time may } \\
\text { indicate the need for evaluation of an individual by a clinical } \\
\text { specialist [25]. }\end{array}$ \\
\hline
\end{tabular}


Table 7. Cont.

\begin{tabular}{cl}
\hline Recommendation & Explanation \\
\hline & $\begin{array}{l}\text { Effective mood regulation is highly individualized, with many } \\
\text { potential regulation strategies available [74,75]. Some may be } \\
\text { effective in the short term (e.g., using music to relax or arouse }\end{array}$ \\
[76]) and others may have longer term mental health benefits \\
(e.g., relaxation/mindfulness training, yoga [77,78]). Some \\
maladaptive mood \\
regulation strategies. \\
habitual coping strategies may pose a threat to health (e.g., \\
excessive alcohol consumption [79]) or to performance (e.g., \\
negative self-talk [80]). Identifying the adaptive mood regulation \\
strategies that work best for individuals is a key element in \\
effective mood profiling.
\end{tabular}

Although the focus of this paper has been on mental health among athletes, especially at the elite level, the same principles of using mood profiling to monitor emotional responses apply to everyday life and to non-athletes. Results of previous studies $[4,19,21,22]$ have confirmed that the same six mood profile clusters evident among athletes are also evident in the normal population, and across different language and cultural groups. More specifically, the six mood profile clusters shown in Figure 1 have also been identified among Italian athletes and exercisers [21], among athletes and non-athletes in Singapore [22] and China [82], and among youth athletes in Brazil [83]. Evidence has accrued related to the benefits of the iceberg profile for performance in sport $[84,85]$ and academic examinations $[86,87]$. The iceberg profile has also long been associated with athlete mental health $[7,73]$. Conversely, an increased risk of mental ill-health has been established for athletes and nonathletes reporting the inverse iceberg and especially the inverse Everest profiles [17,25]. Little is known, however, about the antecedents, correlates, and behavioural consequences of the shark fin, submerged, and surface profiles, and further investigation of those profiles is warranted. Finally, it is recommended that researchers and applied practitioners who use the BRUMS for mood assessment apply the revised tables of normative data reported herein rather than those reported previously [12,31].

Author Contributions: Conceptualization, P.C.T. and R.L.P.-S.; methodology, P.C.T.; validation, P.C.T. and R.L.P.-S.; formal analysis, P.C.T. and R.L.P.-S.; investigation, P.C.T. and R.L.P.-S.; resources, P.C.T.; data curation, R.L.P.-S.; writing-original draft preparation, P.C.T. and R.L.P.-S.; writing-review and editing, P.C.T. and R.L.P.-S.; visualization, P.C.T. and R.L.P.-S.; project administration, P.C.T. All authors have read and agreed to the published version of the manuscript.

Funding: This research received no external funding.

Institutional Review Board Statement: The study was conducted according to the guidelines of the Declaration of Helsinki and approved by the Human Research Ethics Committee of the University of Southern Queensland (approval numbers H11REA023, H13REA169, H16REA015).

Informed Consent Statement: Informed consent was obtained from all subjects involved in the study. 
Data Availability Statement: Data supporting the reported results can be accessed at https:/ / eprints. usq.edu.au/40412/ (accessed on 28 May 2021).

Acknowledgments: The intellectual contribution of the late Gerry Tehan to an earlier stage of this project is acknowledged. We thank the three reviewers for their constructive feedback, which helped to improve the quality of our manuscript.

Conflicts of Interest: The authors declare no conflict of interest.

\section{Appendix A}

\begin{tabular}{|c|c|c|c|c|c|c|c|c|}
\hline \multicolumn{3}{|l|}{ Name: } & \multicolumn{2}{|c|}{ Age: } & \multicolumn{2}{|c|}{ Gender: } & \multirow[t]{2}{*}{ Date: } & \multirow{3}{*}{$\begin{array}{l}/ / \\
\text { T-Score }\end{array}$} \\
\hline & \multirow{2}{*}{ T-Score } & \multicolumn{5}{|c|}{ FACTOR } & & \\
\hline & & Tension & Depression & Anger & Vigour & Fatigue & Confusion & \\
\hline & $z 90$ & & 215 & 215 & & & 215 & 290 \\
\hline & 89 & 16 & & & & & & 89 \\
\hline & 88 & & 14 & 14 & & & & 88 \\
\hline & 87 & & & & & & 14 & 87 \\
\hline & 86 & 15 & & & & & & 86 \\
\hline & 85 & & & 13 & & & & 85 \\
\hline & 84 & & 13 & & & & 13 & 84 \\
\hline & 83 & 14 & & & & & & 83 \\
\hline & 82 & & & & & & & 82 \\
\hline & 81 & & 12 & 12 & & & 12 & 81 \\
\hline & 80 & 13 & & & & & & 80 \\
\hline & 79 & & & & & & & 79 \\
\hline & 78 & & 11 & 11 & & & & 78 \\
\hline & 77 & 12 & & & & 16 & 11 & 77 \\
\hline & 76 & & & & & & & 76 \\
\hline a & 75 & & 10 & 10 & & 15 & & 75 \\
\hline$\omega$ & 74 & 11 & & & & & 10 & 74 \\
\hline & 73 & & & & & & & 73 \\
\hline & 72 & & 9 & 9 & 16 & 14 & & 72 \\
\hline & 71 & 10 & & & & & 9 & 71 \\
\hline & 70 & & & & 15 & 13 & & 70 \\
\hline & 69 & & 8 & 8 & & & & 69 \\
\hline 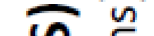 & 68 & 9 & & & & & 8 & 68 \\
\hline$E$ & 67 & & & & 14 & 12 & & 67 \\
\hline$\frac{1}{2}$ & 66 & & & & & & & 66 \\
\hline$\stackrel{0}{\longrightarrow}$ & 65 & 8 & 7 & 7 & 13 & 11 & & 65 \\
\hline$z$ & 64 & & & & & & 7 & 64 \\
\hline$ᄃ$ & 63 & & & & & & & 63 \\
\hline 0 & 62 & 7 & 6 & 6 & 12 & 10 & & 62 \\
\hline & 61 & & & & & & 6 & 61 \\
\hline$\pi$ & 60 & & & & & & & 60 \\
\hline$\overline{7}$ & 59 & 6 & 5 & 5 & 11 & 9 & & 59 \\
\hline $\overrightarrow{8}$ & 58 & & & & & & 5 & 58 \\
\hline$\frac{1}{0}$ & 57 & & & & 10 & 8 & & 57 \\
\hline 0 & 56 & 5 & 4 & 4 & & & & 56 \\
\hline & 55 & & & & & & 4 & 55 \\
\hline & 54 & & & & 9 & 7 & & 54 \\
\hline & 53 & 4 & 3 & 3 & & & & 53 \\
\hline & 52 & & & & 8 & 6 & 3 & 52 \\
\hline & 51 & & & & & & & 51 \\
\hline & 50 & 3 & 2 & & 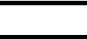 & - & & 50 \\
\hline & 49 & & & 2 & 7 & 5 & & 49 \\
\hline & 48 & & & & & & 2 & 48 \\
\hline & 47 & 2 & & & & 4 & & 47 \\
\hline & 46 & & 1 & 1 & 6 & & & 46 \\
\hline & 45 & & & & & & 1 & 45 \\
\hline$\infty$ & 44 & 1 & & & 5 & 3 & & 44 \\
\hline & 43 & & 0 & 0 & & & & 43 \\
\hline & 42 & & & & & 2 & 0 & 42 \\
\hline & 41 & 0 & & & 4 & & & 41 \\
\hline & 40 & & & & & & & 40 \\
\hline & 39 & & & & & 1 & & 39 \\
\hline & 38 & & & & 3 & & & 38 \\
\hline & 37 & & & & & 0 & & 37 \\
\hline & 36 & & & & 2 & & & 36 \\
\hline & 35 & & & & & & & 35 \\
\hline & 34 & & & & & & & 34 \\
\hline & 33 & & & & 1 & & & 33 \\
\hline & 32 & & & & & & & 32 \\
\hline & 31 & & & & 0 & & & 31 \\
\hline & $\leq 30$ & & & & & & & $\leq 30$ \\
\hline
\end{tabular}

Figure A1. BRUMS Profile Sheet (Population Norms). 


\begin{tabular}{|c|c|c|c|c|c|c|c|c|}
\hline \multicolumn{4}{|l|}{ Name: } & Age: & \multicolumn{2}{|c|}{ Gender: Male } & \multirow[t]{2}{*}{ Date: } & \multirow{3}{*}{$\frac{1}{\text { T-Score }}$} \\
\hline & \multirow{2}{*}{ T-Score } & \multicolumn{5}{|c|}{ FACTOR } & & \\
\hline & & Tension & Depression & Anger & Vigour & Fatigue & Confusion & \\
\hline & 290 & & 215 & 16 & & & 215 & 290 \\
\hline & 89 & 16 & 14 & & & & 14 & 89 \\
\hline & 88 & & & & & & & a8 \\
\hline & 87 & & & 15 & & & & 87 \\
\hline & 86 & 15 & & & & & & 86 \\
\hline & 85 & & 13 & & & & 13 & as \\
\hline & 84 & & & 14 & & & & 84 \\
\hline & 83 & 14 & & & & & & 83 \\
\hline & 82 & & 12 & & & & 12 & $a 2$ \\
\hline & 81 & & & 13 & & & & 81 \\
\hline & 80 & 13 & & & & 16 & & 200 \\
\hline & 79 & & 11 & & & & 11 & 79 \\
\hline & 78 & & & 12 & & 15 & & 78 \\
\hline & 77 & 12 & & & & & & 77 \\
\hline & 76 & & 10 & & & & & 76 \\
\hline & 75 & & & 11 & & 14 & 10 & 75 \\
\hline 0 & 74 & 11 & & & & & & 74 \\
\hline & 73 & & & & & & & 73 \\
\hline & 72 & & 9 & 10 & & 13 & 9 & 72 \\
\hline & 71 & 10 & & & & & & 71 \\
\hline$\pi$ & 70 & & & & 16 & & & 70 \\
\hline$\vec{n}$ & 69 & & 8 & 9 & & 12 & & 69 \\
\hline$E$ & 68 & 9 & & & & & $g$ & 68 \\
\hline 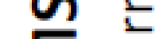 & 67 & & & & 15 & 11 & & 67 \\
\hline$\overline{0}$ & 66 & & 7 & 8 & & & & 66 \\
\hline$\sum$ & 65 & 8 & & & 14 & & 7 & 65 \\
\hline a) & 64 & & & & & 10 & & 64 \\
\hline$\underset{+}{ \pm}$ & 63 & & 6 & 7 & & & & 63 \\
\hline 4 & 62 & 7 & & & 13 & & 6 & 62 \\
\hline $\bar{\varepsilon}$ & 61 & & & & & 9 & & 61 \\
\hline$\stackrel{i}{+}$ & 60 & & & 6 & & & & 60 \\
\hline 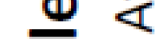 & 59 & 6 & 5 & & 12 & 8 & & 59 \\
\hline$\omega$ & 58 & & & & & & 5 & 58 \\
\hline$\frac{\pi}{\pi}$ & 57 & & & 5 & & & & 57 \\
\hline$\stackrel{\pi}{\infty}$ & 56 & 5 & 4 & & 11 & 7 & & 56 \\
\hline 2 & 55 & & & & & & 4 & 55 \\
\hline & 54 & & & 4 & 10 & & & 54 \\
\hline & 53 & 4 & 3 & & & 6 & & 53 \\
\hline & 52 & & & & & & 3 & 52 \\
\hline & 51 & & & 3 & 9 & & & 51 \\
\hline & 50 & 3 & & & & 5 & & 50 \\
\hline & 49 & & 2 & & & & & 49 \\
\hline & 48 & & & 2 & 8 & 4 & 2 & 48 \\
\hline & 47 & 2 & & & & & & 47 \\
\hline & 46 & & 1 & & 7 & & & 46 \\
\hline & 45 & & & 1 & & 3 & 1 & 45 \\
\hline $\mathrm{e}$ & 44 & 1 & & & & & & 44 \\
\hline & 43 & & 0 & & 6 & & & 43 \\
\hline & 42 & & & 0 & & 2 & & 42 \\
\hline & 41 & 0 & & & & & 0 & 41 \\
\hline & 40 & & & & 5 & 1 & & 40 \\
\hline & 39 & & & & & & & 39 \\
\hline & 38 & & & & 4 & & & 30 \\
\hline & 37 & & & & & 0 & & 37 \\
\hline & 36 & & & & & & & 36 \\
\hline & 35 & & & & 3 & & & 35 \\
\hline & 34 & & & & & & & 34 \\
\hline & 33 & & & & & & & 33 \\
\hline & 32 & & & & 2 & & & 32 \\
\hline & 31 & & & & & & & 31 \\
\hline & $\leq 30$ & & & & $\leq 1$ & & & $\leq 30$ \\
\hline
\end{tabular}

Figure A2. BRUMS Profile Sheet (Male Athletes). 


\begin{tabular}{|c|c|c|c|c|c|c|c|c|}
\hline \multicolumn{4}{|l|}{ Name: } & Age: & \multicolumn{2}{|c|}{ Gender: Female } & \multirow[t]{2}{*}{ Date: } & \multirow{3}{*}{$\begin{array}{c}/ \\
\text { T-Score }\end{array}$} \\
\hline & \multirow{2}{*}{ T-Score } & \multicolumn{5}{|c|}{ FACTOR } & & \\
\hline & & Tension & Depression & Anger & Vigour & Fatigue & Confusion & \\
\hline & 290 & & 16 & 16 & & & 215 & 290 \\
\hline & 69 & & & & & & & 89 \\
\hline & 80 & & & & & & & 38 \\
\hline & 87 & & 15 & 15 & & & & a7 \\
\hline & 86 & & & & & & & 86 \\
\hline & 85 & & & & & & 14 & 95 \\
\hline & 84 & 16 & 14 & 14 & & & & 84 \\
\hline & 83 & & & & & & & 93 \\
\hline & 82 & 15 & & & & & 13 & 82 \\
\hline & 81 & & 13 & 13 & & & & 81 \\
\hline & 80 & & & & & & & 80 \\
\hline & 79 & 14 & & & & & 12 & 79 \\
\hline & 78 & & 12 & 12 & & & & 78 \\
\hline & 77 & & & & & & & 77 \\
\hline & 76 & 13 & & & & & 11 & 76 \\
\hline & 75 & & 11 & 11 & & 16 & & 75 \\
\hline & 74 & & & & & & & 74 \\
\hline & 73 & 12 & & & & & & 73 \\
\hline & 72 & & 10 & 10 & 16 & 15 & 10 & 72 \\
\hline & 71 & & & & & & & 71 \\
\hline$\vec{n}$ & 70 & 11 & & & & 14 & & 70 \\
\hline$\varnothing$ & 69 & & 9 & 9 & 15 & & 9 & 69 \\
\hline$E$ & 68 & & & & & & & 68 \\
\hline$\overline{\mathrm{O}}$ & 67 & 10 & & & & 13 & & 67 \\
\hline$\sum$ & 66 & & 8 & 8 & 14 & & 8 & 66 \\
\hline & 65 & 9 & & & & 12 & & 65 \\
\hline$\underset{+}{\Psi}$ & 64 & & & & 13 & & & 64 \\
\hline $\bar{u}$ & 63 & & 7 & 7 & & & 7 & 63 \\
\hline $\bar{\digamma}$ & 62 & 8 & & & & 11 & & 62 \\
\hline$\frac{1}{ \pm}$ & 61 & & & & 12 & & & 61 \\
\hline$<$ & 60 & & 6 & 6 & & 10 & & 60 \\
\hline (1) & 59 & 7 & & & & & 6 & 59 \\
\hline$\frac{\Phi}{\pi}$ & 58 & & & & 11 & & & 58 \\
\hline $\mathbb{0}$ & 57 & & 5 & 5 & & 9 & & 57 \\
\hline$E$ & 56 & 6 & & & & & 5 & 56 \\
\hline$\overline{\mathscr{U}}$ & 55 & & & & 10 & a & & 55 \\
\hline ப & 54 & & 4 & 4 & & & & 54 \\
\hline & 53 & 5 & & & 9 & & 4 & 53 \\
\hline & 52 & & & & & 7 & & 52 \\
\hline & 51 & & 3 & 3 & . & & & 51 \\
\hline & 50 & 4 & & & 8 & 6 & 3 & 50 \\
\hline & 49 & & & & & & & 49 \\
\hline & 48 & 3 & 2 & 2 & & & & 48 \\
\hline & 47 & & & & 7 & 5 & & 47 \\
\hline & 46 & & & & & & 2 & 46 \\
\hline & 45 & 2 & 1 & 1 & 6 & 4 & & 45 \\
\hline & 44 & & & & & & & 44 \\
\hline & 43 & & & & & 3 & 1 & 43 \\
\hline & 42 & 1 & 0 & 0 & 5 & & & 42 \\
\hline & 41 & & & & & & & 41 \\
\hline & 40 & & & & & 2 & 0 & 40 \\
\hline & 39 & 0 & & & 4 & & & 39 \\
\hline & 38 & & & & & 1 & & 38 \\
\hline & 37 & & & & & & & 37 \\
\hline & 36 & & & & 3 & & & 36 \\
\hline & 35 & & & & & 0 & & 35 \\
\hline & 34 & & & & 2 & & & 34 \\
\hline & 33 & & & & & & & 33 \\
\hline & 32 & & & & & & & 32 \\
\hline & 31 & & & & 1 & & & 31 \\
\hline & $\leq 30$ & & & & 0 & & & $\leq 30$ \\
\hline
\end{tabular}

Figure A3. BRUMS Profile Sheet (Female Athletes). 


\begin{tabular}{|c|c|c|c|c|c|c|c|c|}
\hline \multicolumn{4}{|l|}{ Name: } & Age: & \multicolumn{2}{|c|}{ Gender: Male } & \multirow[t]{2}{*}{ Date: } & \multirow{3}{*}{$\begin{array}{c}/ \\
\text { T-score }\end{array}$} \\
\hline & \multirow{2}{*}{ T-Score } & \multicolumn{5}{|c|}{ FACTOR } & & \\
\hline & & Tension & Depression & Anger & Vigour & Fatigue & Confusion & \\
\hline & 290 & 16 & 215 & 215 & & & 215 & 290 \\
\hline & 89 & 15 & & & & & & 89 \\
\hline & 98 & & 14 & 14 & & & 14 & 88 \\
\hline & 87 & & & & & & & 87 \\
\hline & 86 & 14 & & & & & & 86 \\
\hline & 85 & & 13 & 13 & & & 13 & 85 \\
\hline & 84 & & & & & & & 84 \\
\hline & 83 & & & & & & & 83 \\
\hline & 82 & 13 & 12 & 12 & & & 12 & 82 \\
\hline & 81 & & & & & & & 81 \\
\hline & 80 & & & & & & & 80 \\
\hline & 79 & 12 & 11 & 11 & & & & 79 \\
\hline & 78 & & & & & 16 & 11 & 78 \\
\hline & 77 & & & & & & & 77 \\
\hline 8 & 76 & 11 & & & & & & 76 \\
\hline & 75 & & 10 & 10 & & 15 & 10 & 75 \\
\hline & 74 & & & & & & & 74 \\
\hline & 73 & 10 & & & & 14 & & 73 \\
\hline & 72 & & 9 & 9 & 16 & & 9 & 72 \\
\hline & 71 & & & & & & & 71 \\
\hline$\varepsilon$ & 70 & 9 & & & & 13 & & 70 \\
\hline$\varepsilon$ & 69 & & 8 & 8 & 15 & & & 69 \\
\hline$\overline{0}$ & 68 & & & & & 12 & 8 & 68 \\
\hline$Z$ & 67 & $B$ & & & 14 & & & 67 \\
\hline & 66 & & 7 & 7 & & & & 66 \\
\hline$\underset{+}{\mathscr{U}}$ & 65 & & & & & 11 & 7 & 65 \\
\hline $\bar{\Psi}$ & 64 & 7 & & & 13 & & & 64 \\
\hline $\bar{\sigma}$ & 63 & & 6 & & & 10 & & 63 \\
\hline$\frac{c}{+}$ & 62 & & & 6 & 12 & & 6 & 62 \\
\hline$<$ & 61 & & & & & & & 61 \\
\hline & 60 & 6 & & & & 9 & & 60 \\
\hline$\frac{5}{8}$ & 59 & & 5 & 5 & 11 & & 5 & 59 \\
\hline & 58 & & & & & 8 & & 58 \\
\hline$<$ & 57 & 5 & & & & & & 57 \\
\hline $\mathbb{1}$ & 56 & & 4 & 4 & 10 & & & 56 \\
\hline $\bar{\pi}$ & 55 & & & & & 7 & 4 & 55 \\
\hline & 54 & 4 & & & 9 & & & 54 \\
\hline & 53 & & 3 & 3 & & 6 & & 53 \\
\hline 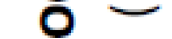 & 52 & & & & & & 3 & 52 \\
\hline & 51 & 3 & & & 8 & & & 51 \\
\hline & 50 & & 2 & 2 & & 5 & & 50 \\
\hline & 49 & & & & & & 2 & 49 \\
\hline & 48 & 2 & & & 7 & & & 48 \\
\hline & 47 & & 1 & & & 4 & & 47 \\
\hline & 46 & & & 1 & 6 & & & 46 \\
\hline & 45 & 1 & & & & 3 & 1 & 45 \\
\hline & 44 & & 0 & & & & & 44 \\
\hline & 43 & & & 0 & 5 & & & 43 \\
\hline & 42 & 0 & & & & 2 & 0 & 42 \\
\hline & 41 & & & & 4 & & & 41 \\
\hline & 40 & & & & & 1 & & 40 \\
\hline & 39 & & & & & & & 39 \\
\hline & 38 & & & & 3 & & & 38 \\
\hline & 37 & & & & & 0 & & 37 \\
\hline & 36 & & & & & & & 36 \\
\hline & 35 & & & & 2 & & & 35 \\
\hline & 34 & & & & & & & 34 \\
\hline & 33 & & & & 1 & & & 33 \\
\hline & 32 & & & & & & & 32 \\
\hline & 31 & & & & & & & 31 \\
\hline & $\leq 30$ & & & & 0 & & & $\leq 30$ \\
\hline
\end{tabular}

Figure A4. BRUMS Profile Sheet (Male Non-Athletes). 


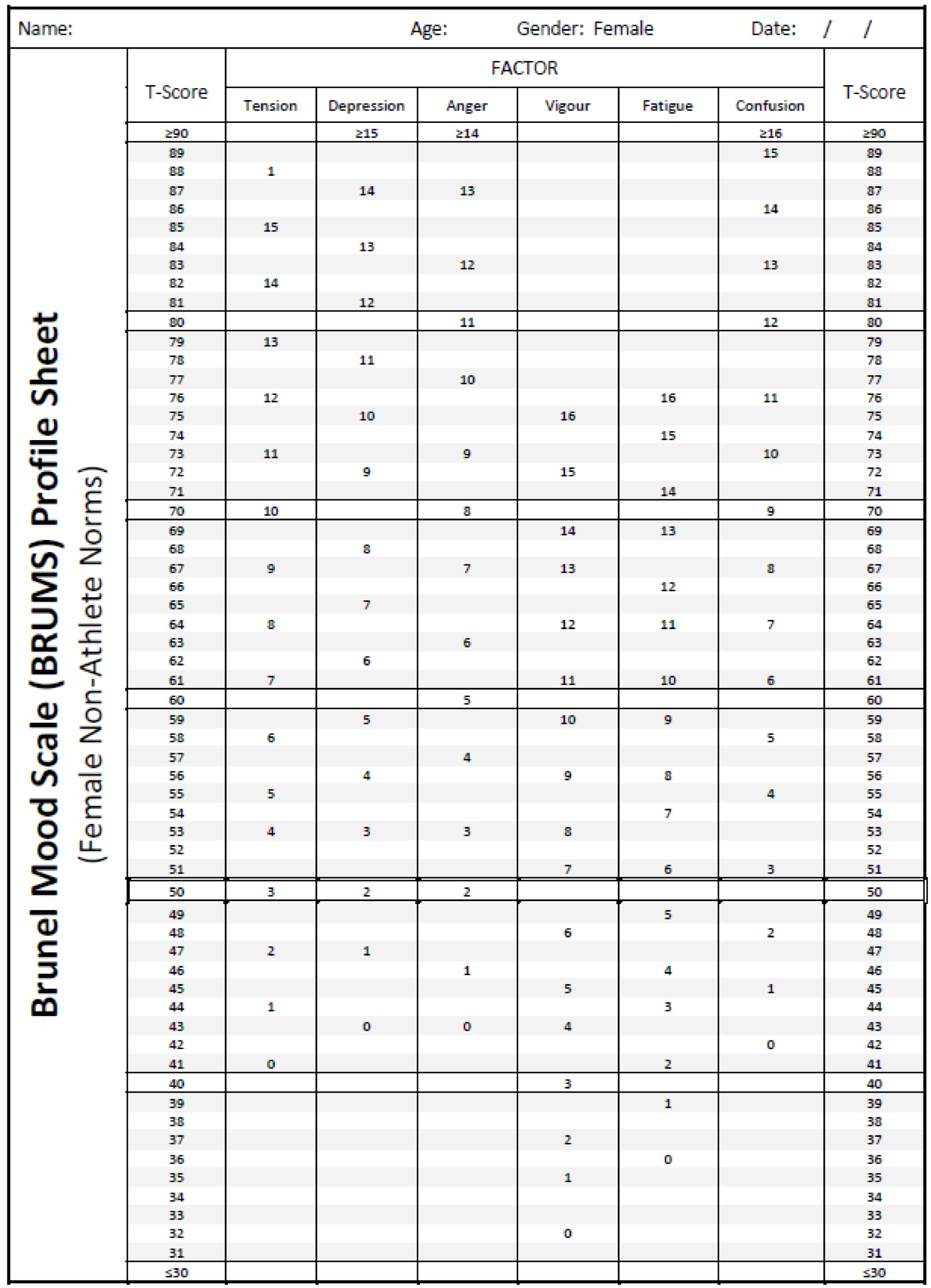

Figure A5. BRUMS Profile Sheet (Female Non-Athletes). 


\section{References}

1. Ritchie, H.; Roser, M. Mental Health. 2018. Available online: https:/ / ourworldindata.org/mental-health (accessed on 6 January 2021).

2. Ammar, A.; Chtourou, H.; Boukhris, O.; Trabelsi, K.; Masmoudi, L.; Brach, M.; Bouaziz, B.; Bentlage, E.; How, D.; Ahmed, M.; et al. COVID-19 home confinement negatively impacts social participation and life satisfaction: A worldwide multicenter study. Int. J. Environ. Res. Public Health 2020, 17, 6237. [CrossRef] [PubMed]

3. Pappa, S.; Ntella, V.; Giannakas, T.; Giannakoulis, V.G.; Papoutsi, E.; Katsaounou, P. Prevalence of depression, anxiety, and insomnia among healthcare workers during the COVID-19 pandemic: A systematic review and meta-analysis. Brain Behav. Immun. 2020, 88, 901-907. [CrossRef] [PubMed]

4. Terry, P.C.; Parsons-Smith, R.L.; Terry, V.R. Mood responses associated with COVID-19 restrictions. Front. Psychol. 2020, 11, 589598. [CrossRef] [PubMed]

5. Reardon, C.L.; Bindra, A.; Blauwet, C.; Budgett, R.; Campriani, N.; Currie, A.; Gouttebarge, V.; McDuff, D.; Mountjoy, M.; Purcell, R.; et al. Mental health management of elite athletes during COVID-19: A narrative review and recommendations. Br. J. Sports Med. 2020. [CrossRef] [PubMed]

6. Mon-López, D.; García-Aliaga, A.; Bartolomé, A.G.; Solana, D.M. How has COVID-19 modified training and mood in professional and non-professional football players? Physiol. Behav. 2020, 227, 113148. [CrossRef] [PubMed]

7. Morgan, W.P. Selected psychological factors limiting performance: A mental health model. In Limits of Human Performance; Clarke, D.H., Eckert, H.M., Eds.; Human Kinetics: Champaign, IL, USA, 1985; pp. 70-80.

8. Kline, T.J.B. Psychological Testing; Sage Publishing: Thousand Oaks, CA, USA, 2005.

9. LeUnes, A.; Burger, J. Profile of Mood States research in sport and exercise psychology: Past, present, and future. J. Appl. Sport Psychol. 2000, 12, 5-15. [CrossRef]

10. Terry, P.C.; Lane, A.M. Moods and emotions. In The New Sport and Exercise Psychology Companion; Morris, T., Terry, P.C., Eds.; Fitness Information Technology: Morgantown, WV, USA, 2011; pp. 63-87.

11. Terry, P.C.; Lane, A.; Lane, H.J.; Keohane, L. Development and validation of a mood measure for adolescents. J. Sports Sci. 1999, 17, 861-872. [CrossRef]

12. Terry, P.; Lane, A.; Fogarty, G. Construct validity of the Profile of Mood States-Adolescents for use with adults. Psychol. Sport Exerc. 2003, 4, 125-139. [CrossRef]

13. McNair, D.M.; Lorr, M.; Droppelman, L.F. Manual for the Profile of Mood States, 1st ed.; Educational and Industrial Testing Services: San Diego, CA, USA, 1971.

14. McNair, D.M.; Lorr, M.; Droppelman, L.F. Revised Manual for the Profile of Mood States, 2nd ed.; Educational and Industrial Testing Services: San Diego, CA, USA, 1992.

15. Morgan, W.P. Test of champions: The iceberg profile. Psychol. Today 1980, 14, 92-108.

16. Morgan, W.P.; Brown, D.R.; Raglin, J.S.; O'Connor, P.J.; Ellickson, K.A. Psychological monitoring of overtraining and staleness. Br. J. Sports Med. 1987, 21, 107-114. [CrossRef]

17. Budgett, R. Overtraining syndrome. Br. J. Sports Med. 1990, 24, 231-236. [CrossRef]

18. Terry, P. The efficacy of mood state profiling with elite performers: A review and synthesis. Sport Psychol. 1995, 9, 309-324. [CrossRef]

19. Parsons-Smith, R.L.; Terry, P.C.; Machin, M.A. Identification and description of novel mood profile clusters. Front. Psychol. 2017, 8, 1958. [CrossRef]

20. Terry, P.; Parsons-Smith, R. Identification and incidence of mood profile clusters among sport participants. J. Sci. Med. Sport 2019, 22, S100. [CrossRef]

21. Quartiroli, A.; Parsons-Smith, R.L.; Fogarty, G.J.; Kuan, G.; Terry, P.C. Cross-cultural validation of mood profile clusters in a sport and exercise context. Front. Psychol. 2018, 9, 1949. [CrossRef]

22. Han, C.S.Y.; Parsons-Smith, R.L.; Terry, P.C. Mood profiling in Singapore: Cross-cultural validation and potential applications of mood profile clusters. Front. Psychol. 2020, 11, 665. [CrossRef]

23. Terry, P.C.; Parsons-Smith, R.L.; King, R.; Terry, V.R. Influence of sex, age, and education on mood profile clusters. PLoS ONE 2021, 16, e0245341. [CrossRef]

24. Terry, P.C.; Karageorghis, C.I.; Saha, A.M.; D'Auria, S. Effects of synchronous music on treadmill running among elite triathletes. J. Sci. Med. Sport 2012, 15, 52-57. [CrossRef]

25. Van Wijk, C.H.; Martin, J.H.; Hans-Arendse, C. Clinical utility of the Brunel Mood Scale in screening for post-traumatic stress risk in a military population. Mil. Med. 2013, 178, 372-376. [CrossRef]

26. Brandt, R.; Herrero, D.; Massetti, T.; Crocetta, T.B.; Guarnieri, R.; Monteiro, C.B.D.M.; Viana, M.D.S.; Bevilacqua, G.G.; de Abreu, L.C.; Andrade, A. The Brunel Mood Scale rating in mental health for physically active and apparently healthy populations. Health 2016, 8, 125-132. [CrossRef]

27. Sties, S.W.; Gonzáles, A.I.; Netto, A.S.; Wittkopf, P.G.; Lima, D.P.; De Carvalho, T. Validação da escala de humor de brunel para programa de reabilitação cardiovascular. Rev. Bras. Med. Esporte 2014, 20, 281-284. [CrossRef]

28. Yatabe, K.; Yui, N.; Kasuya, S.; Fujiya, H.; Tateishi, K.; Terawaki, F.; Musha, H. Anxiety and Mood among Ballet Dancers: A Pilot Study on Effects of a Medical Approach Involving Periodic Intervention. 2014. Available online: https://www.researchgate.net/ publication/272791152 (accessed on 6 January 2021). 
29. Gould, M.S.; Marrocco, F.A.; Kleinman, M.; Thomas, J.G.; Mostkoff, K.; Côté, J.; Davies, M. Evaluating iatrogenic risk of youth suicide screeningp. JAMA 2005, 293, 1635-1643. [CrossRef]

30. Terry, P.C.; Lane, A.M. Normative values for the Profile of Mood States for use with athletic samples. J. Appl. Sport Psychol. 2000, 12, 93-109. [CrossRef]

31. Terry, P.C.; Lane, A.M. User Guide for the Brunel Mood Scale; Peter Terry Consultants: Toowoomba, Australia, 2010.

32. Terry, P.C.; Potgieter, J.R.; Fogarty, G.J. The Stellenbosch Mood Scale: A dual-language measure of mood. Int. J. Sport Exerc. Psychol. 2003, 1, 231-245. [CrossRef]

33. Rohlfs, I.C.P.D.M.; Rotta, T.M.; Luft, C.D.B.; Krebs, R.J.; Andrade, A.; De Carvalho, T. A Escala de Humor de Brunel (Brums): Instrumento para detecção precoce da síndrome do excesso de treinamento. Rev. Bras. Med. Esporte 2008, 14, 176-181. [CrossRef]

34. Zhang, C.-Q.; Si, G.; Chung, P.-K.; Du, M.; Terry, P.C. Psychometric properties of the Brunel Mood Scale in Chinese adolescents and adults. J. Sports Sci. 2014, 32, 1-12. [CrossRef] [PubMed]

35. Květon, P.; Jelínek, M.; Burešová, I.; Bartošová, K. Czech adaptation of the Brunel Mood States for adolescent athletes. Studia Sport. 2020, 14, 47-57. [CrossRef]

36. Rouveix, M.; Duclos, M.; Gouarne, C.; Beauvieux, M.; Filaire, E. The $24 \mathrm{~h}$ Urinary cortisol/cortisone ratio and epinephrine/norepinephrine ratio for monitoring training in young female tennis players. Int. J. Sports Med. 2006, 27, 856-863. [CrossRef]

37. Lane, A.M.; Soos, I.; Leibinger, E.; Karsai, I.; Hamar, P. Validity of the Brunel Mood Scale for use with UK, Italian and Hun-garian athletes. In Mood and Human Performance: Conceptual, Measurement, and Applied Issues; Lane, A.M., Ed.; Nova Science: Hauppauge, NY, USA, 2007; pp. 119-130.

38. Quartiroli, A.; Terry, P.C.; Fogarty, G.J. Development and initial validation of the Italian Mood Scale (ITAMS) for use in sport and exercise contexts. Front. Psychol. 2017, 8, 1483. [CrossRef]

39. Yatabe, K.; Oyama, T.; Fujiya, H.; Kato, H.; Seki, H.; Kohno, T. Development and validation of the preliminary Japanese version of the Profile of Mood States for Adolescents. St. Marian. Med. J. 2006, 32, 539-547.

40. Hashim, H.A.; Zulkifli, E.Z.; Yusof, H.A. Factorial validation of Malaysian adapted Brunel Mood Scale in an adolescent sample. Asian J. Sport Med. 2010, 1, 185. Available online: https://www.ncbi.nlm.nih.gov/pmc/articles/PMC3289187/ (accessed on 6 January 2021). [CrossRef]

41. Lan, M.F.; Lane, A.M.; Roy, J.; Hanin, N.A. Validity of the Brunel Mood Scale for use with Malaysian athletes. J. Sports Sci. Med. 2012, 11, 131-135.

42. Terry, P.C.; Malekshahi, M.; Delva, H.A. Development and initial validation of the Farsi Mood Scale. Int. J. Sport Exerc. Psychol. 2012, 10, 112-122. [CrossRef]

43. Han, C.; Parsons-Smith, R.L.; Fogarty, G.J.; Terry, P.C. Psychometric properties of the Brunel Mood Scale in a Singaporean sporting context. Int. J. Sport Exer. Psychol. 2021, 19. [CrossRef]

44. Cañadas, E.; Monleón, C.; Sanchis, C.; Fargueta, M.; Blasco, E. Spanish validation of BRUMS in sporting and non-sporting populations. Eur. J. Hum. Mov. 2017, 38, 105-117. Available online: http://www.eurjhm.com/index.php/eurjhm/article/view/ 413/608 (accessed on 6 January 2021).

45. Çakiroğlu1, A.A.; Demir, E.; Güçlü, M. The validity and reliability study of the Brunel Mood Scale with the adult athletes (Turkish Adaptation). Int. J. Appl. Exerc. Physiol. 2020, 9, 126-140. Available online: http://ijaep.com/Journal/vol.9.10.pdf (accessed on 28 May 2021).

46. Ekkekakis, P. The Measurement of Affect, Mood, and Emotion: A Guide for Health-Behavioral Research; Cambridge University Press: New York, NY, USA, 2013.

47. Terry, P.C.; Lim, J.; Parsons-Smith, R.L. In The Mood: An online mood assessment based on the Brunel Mood Scale. 2013. Available online: www.moodprofling.com (accessed on 6 January 2021).

48. IBM Corp. IBM SPSS Statistics for Windows; Version 27.0; IBM Corp.: Armonk, NY, USA, 2020.

49. Cohen, J. A power primer. Psychol. Bull. 1992, 112, 155-159. [CrossRef]

50. Tabachnick, B.L.; Fidell, L.S. Using Multivariate Statistics, 7th ed.; Pearson Education: Boston, MA, USA, 2019.

51. Chang, C.; Putukian, M.; Aerni, G.; Diamond, A.; Hong, G.; Ingram, Y.; Reardon, C.L.; Wolanin, A. Mental health issues and psychological factors in athletes: Detection, management, effect on performance and prevention: American Medical Society for Sports Medicine Position Statement-Executive Summary. Br. J. Sports Med. 2019, 54, 216-220. [CrossRef]

52. Henriksen, K.; Schinke, R.; Moesch, K.; McCann, S.; Parham, W.D.; Larsen, C.H.; Terry, P. Consensus statement on improving the mental health of high-performance athletes. Int. J. Sport Exerc. Psychol. 2019, 18, 553-560. [CrossRef]

53. Moesch, K.; Kenttä, G.; Kleinert, J.; Quignon-Fleuret, C.; Cecil, S.; Bertollo, M. FEPSAC position statement: Mental health disorders in elite athletes and models of service provision. Psychol. Sport Exerc. 2018, 38, 61-71. [CrossRef]

54. Schinke, R.J.; Stambulova, N.B.; Si, G.; Moore, Z. International society of sport psychology position stand: Athletes' mental health, performance, and development. Int. J. Sport Exerc. Psychol. 2018, 16, 622-639. [CrossRef]

55. Reardon, C.L.; Hainline, B.; Aron, C.M.; Baron, D.; Baum, A.L.; Bindra, A.; Budgett, R.; Campriani, N.; Castaldelli-Maia, J.M.; Currie, A.; et al. Mental health in elite athletes: International Olympic Committee consensus statement (2019). Br. J. Sports Med. 2019, 53, 667-699. [CrossRef] [PubMed]

56. Purcell, R.; Gwyther, K.; Rice, S.M. Mental health in elite athletes: Increased awareness requires an early intervention framework to respond to athlete needs. Sports Med. Open 2019, 5, 1-8. [CrossRef] [PubMed] 
57. Galambos, S.A.; Terry, P.C.; Moyle, G.M.; Locke, S.A. Psychological predictors of injury among elite athletes. Br. J. Sports Med. 2005, 39, 351-354. [CrossRef]

58. Kleinert, J. Mood states and perceived physical states as short-term predictors of sport injuries: Two prospective studies. Int. J. Sport Exerc. Psychol. 2007, 5, 340-351. [CrossRef]

59. Rice, S.M.; Gwyther, K.; Santesteban-Echarri, O.; Baron, D.; Gorczynski, P.; Gouttebarge, V.; Reardon, C.L.; Hitchcock, M.E.; Hainline, B.; Purcell, R. Determinants of anxiety in elite athletes: A systematic review and meta-analysis. Br. J. Sports Med. 2019, 53, 722-730. [CrossRef]

60. Gouttebarge, V.; Castaldelli-Maia, J.M.; Gorczynski, P.; Hainline, B.; Hitchcock, M.E.; Kerkhoffs, G.M.; Rice, S.M.; Reardon, C.L. Occurrence of mental health symptoms and disorders in current and former elite athletes: A systematic review and meta-analysis. Br. J. Sports Med. 2019, 53, 700-706. [CrossRef]

61. Sundgot-Borgen, J.; Torstveit, M.K. Prevalence of eating disorders in elite athletes is higher than in the general population. Clin. J. Sport Med. 2004, 14, 25-32. [CrossRef]

62. Smolak, L.; Murnen, S.K.; Ruble, A.E. Female athletes and eating problems: A meta-analysis. Int. J. Eat. Disord. 2000, 27, 371-380. [CrossRef]

63. Karrer, Y.; Halioua, R.; Mötteli, S.; Iff, S.; Seifritz, E.; Jäger, M.; Claussen, M.C. Disordered eating and eating disorders in male elite athletes: A scoping review. BMJ Open Sport Exerc. Med. 2020, 6, e000801. [CrossRef]

64. Martinsen, M.; Sundgot-Borgen, J. Higher prevalence of eating disorders among adolescent elite athletes than controls. Med. Sci. Sports Exerc. 2013, 45, 1188-1197. [CrossRef]

65. Godart, N.; Radon, L.; Curt, F.; Duclos, J.; Perdereau, F.; Lang, F.; Venisse, J.; Halfon, O.; Bizouard, P.; Loas, G.; et al. Mood disorders in eating disorder patients: Prevalence and chronology of onset. J. Affect. Disord. 2015, 185, 115-122. [CrossRef]

66. McCann, S. At the Olympics, everything is a performance issue. Int. J. Sport Exerc. Psychol. 2008, 6, 267-276. [CrossRef]

67. Budgett, R.; Newsholme, E.; Lehmann, M.; Sharp, C.; Jones, D.; Jones, T.; Peto, T.; Collins, D.; Nerurkar, R.; White, P. Redefining the overtraining syndrome as the unexplained underperformance syndrome. Br. J. Sports Med. 2000, 34, 67-68. [CrossRef]

68. Eaton, J. Reverse therapy: Chronic fatigue. In Fibromyalgia and Related Disorders; Dr. John Eaton: London, UK, $2017 ;$ pp. 1-176.

69. Terry, P.C. Sick and tired of being sick and tired: Case study of an international kayaker's recovery from chronic fatigue syn-drome and psychological preparation for the world championship. In Case Studies in Sport Science and Medicine; Lane, A.M., Godfrey, R.J., Loosemore, M., Whyte, G.P., Eds.; Amazon Createspace: New York, NY, USA, 2014; pp. 12-16.

70. Gulliver, A.; Griffiths, K.M.; Mackinnon, A.; Batterham, P.J.; Stanimirovic, R. The mental health of Australian elite athletes. J. Sci. Med. Sport 2015, 18, 255-261. [CrossRef]

71. Åkesdotter, C.; Kenttä, G.; Eloranta, S.; Franck, J. The prevalence of mental health problems in elite athletes. J. Sci. Med. Sport 2020, 23, 329-335. [CrossRef]

72. Kuettel, A.; Larsen, C.H. Risk and protective factors for mental health in elite athletes: A scoping review. Int. Rev. Sport Exerc. Psychol. 2019, 13, 231-265. [CrossRef]

73. Raglin, J.S. Psychological factors in sport performance. Sports Med. 2001, 31, 875-890. [CrossRef]

74. Lane, A.M.; Terry, P.C. Online mood profiling and self-regulation of affective responses. In The Routledge International Hand-book of Sport Psychology; Schinke, R., McGannon, K., Smith, B., Eds.; Routledge: Milton Park, UK, 2016; pp. 324-334.

75. Roberts, R.J.; Lane, A.M. Mood responses and regulation strategies used during COVID-19 among boxers and coaches. Front. Psychol. 2021, 12, 624119. [CrossRef]

76. Terry, P.C.; Karageorghis, C.I.; Curran, M.L.; Martin, O.V.; Parsons-Smith, R.L. Effects of music in exercise and sport: A meta-analytic review. Psychol. Bull. 2020, 146, 91-117. [CrossRef]

77. Jekauc, D.; Kittler, C.; Schlagheck, M. Effectiveness of a mindfulness-based intervention for athletes. Psychology 2017, 8, 1-13. [CrossRef]

78. De Manincor, M.; Bensoussan, A.; Smith, C.A.; Barr, K.; Schweickle, M.; Donoghoe, L.-L.; Bourchier, S.; Fahey, P. Individualized yoga for reducing depression and anxiety, and improving well-being: A randomized controlled trial. Depress. Anxiety 2016, 33, 816-828. [CrossRef]

79. Wood, A.M.; Kaptoge, S.; Butterworth, A.S.; Willeit, P.; Warnakula, S.; Bolton, T.; Paige, E.; Paul, D.; Sweeting, M.; Burgess, S.; et al. Risk thresholds for alcohol consumption: Combined analysis of individual-participant data for 599912 current drinkers in 83 prospective studies. Lancet 2018, 391, 1513-1523. [CrossRef]

80. Hatzigeorgiadis, A.; Zourbanos, N.; Galanis, E.; Theodorakis, Y. Self-talk and sport performance: A meta-analysis. Perspect. Psychol. Sci. 2011, 6, 354-362. [CrossRef]

81. Adkins, D.C.; Fiske, D.W. Psychological testing. Encycl Brit. 2017. Available online: https://www.britannica.com/science/ psychological-testing (accessed on 28 May 2021).

82. Terry, P.C.; Parsons-Smith, R.L.; Zhang, C.Q.; Si, G.; Chung, P.K. Mood profile clusters among Chinese athletes and non-athletes Int. J. Sport Exer. Psychol. 2021, in press.

83. Brandão, M.R.F.; Correa, M.; Sermarine, M.; Angelo, D.L.; Parsons-Smith, R.L.; Terry, P.C. Psychometric re-evaluation of the Brazil Mood Scale and evidence of mood profile clusters among youth athletes in Brazil. Int. J. Sport Exer. Psychol. 2021, in press.

84. Beedie, C.J.; Terry, P.C.; Lane, A.M. The Profile of Mood States and athletic performance: Two meta-analyses. J. Appl. Sport Psychol. 2000, 12, 49-68. [CrossRef] 
85. Lochbaum, M.; Zanatta, T.; Kirschling, D.; May, E. The Profile of Mood States and athletic performance: A meta-analysis of published studies. Eur. J. Investig. Health Psychol. Educ. 2021, 11, 50-70. [CrossRef]

86. Lane, A.M.; Whyte, G.P.; Terry, P.C.; Nevill, A.M. Mood, self-set goals and examination performance: The moderating effect of depressed mood. Personal. Individ. Differ. 2005, 39, 143-153. [CrossRef]

87. Thelwell, R.C.; Lane, A.M.; Weston, N.J.V. Mood states, self-set goals, self-efficacy, and performance in academic examinations. Personal. Individ. Differ. 2007, 42, 573-583. [CrossRef] 